\title{
Flight movement and spatial distribution of immunomarked thrips in onion, potato, and tomato
}

\author{
Flávio Lemes Fernandes ${ }^{(1)}$ and Maria Elisa de Sena Fernandes ${ }^{(1)}$
} (1)Universidade Federal de Viçosa, Instituto de Ciências Agrárias, Campus Rio Paranaíba, Rodovia MG-230, Km 7, Caixa Postal 22,
CEP 38810-000 Rio Paranaíba, MG, Brazil. E-mail: flaviofernandes@ufv.br, maria.sena@ufv.br

\begin{abstract}
The objective of this work was to evaluate the spatial distribution of thrips in different crops, and the correlation between meterological parameters and the flight movements of this pest, using immunomarking. The experiment was conducted in cultivated areas, with tomato (Solanum lycopersicum), potato (Solanum tuberosum), and onion (Allium cepa); and non-cultivated areas, with weedy plants. The areas with tomato (100 days), potato (20 days), and weeds were sprayed with casein, albumin, and soy milk, respectively, to mark adult thrips; however, the areas with onion (50 days) and tomato (10 days) were not sprayed. Thrips were captured with georeferenced blue sticky traps, transferred into tubes, and identified by treatment area with the Elisa test. The dependence between the samples and the capture distance was determined using geostatistics. Meteorlogical parameters were correlated with thrips density in each area. The three protein types used for immunomarking were detected in different proportions in the thrips. There was a correlation between casein-marked thrips and wind speed. The thrips flew a maximum distance of $3.5 \mathrm{~km}$ and dispersed from the older (tomato) to the younger crops (potato). The immunomarking method is efficient to mark large quantities of thrips.
\end{abstract}

Index terms: Alliaceae, dispersal pattern, Elisa, integrated pest management, Solanaceae, Thysanoptera.

\section{Movimento de voo e distribuição espacial de tripes imunomarcados em cebola, batata e tomate}

Resumo - O objetivo deste trabalho foi avaliar a distribuição espacial de tripes em diferentes cultivos, e a correlação entre os parâmetros meteorológicos e o movimento de voo dessa praga, com uso de imunomarcação. $\mathrm{O}$ experimento foi conduzido em área cultivada com tomate (Solanum lycopersicum), batata (Solanum tuberosum) e cebola (Allium cepa); e não cultivada, com plantas daninhas. As áreas com tomate (100 dias), batata (20 dias) e plantas daninhas foram pulverizadas com caseína, albumina e leite de soja, respectivamente, para marcar os tripes adultos; no entanto, as áreas com cebola (50 dias) e tomate (10 dias) não foram pulverizadas. Os tripes foram capturados com armadilha adesiva de cor azul georeferenciada, acondicionados em tubos e identificados, por área de tratamento, com o teste de Elisa. Determinou-se a dependência entre as amostras e a distância de captura com uso de geoestatística. Os parâmetros meteorológicos foram correlacionados com a densidade de tripes em cada área. Os três tipos de proteína usados na imunomarcação foram detectados, em diferentes proporções, nos tripes. Houve correlação entre os tripes marcados com caseína e a velocidade do vento. Os tripes voaram uma distância máxima de $3,5 \mathrm{~km}$ e dispersaram dos cultivos mais velhos (tomate) para os mais jovens (batata). O método de imunomarcação é eficiente para marcar grandes quantidades de tripes.

Termos para indexação: Alliaceae, padrão de dispersão, Elisa, manejo integrado de pragas, Solanaceae, Thysanoptera.

\section{Introduction}

Knowledge of the dispersal patterns of insect pest species is of fundamental importance to studies of integrated pest management. These studies enable forecasting where pest outbreaks are likely to occur and are useful for creating pest sampling plans and management tactics (Pedigo \& Rice, 2009). Studies of insect dispersal in different ecosystems have relied on a variety of methods using markers to determine movement patterns. However, these markers are difficult to apply over vast areas, because they are expensive, time-consuming, affect insect behavior, cause environmental degradation, mark only a small portion of the population from a few release points, and fail to mark small insects $(<3 \mathrm{~mm})$ (Hagler \& Jackson, 2001; Hagler et al., 2002; Jones et al., 2006). To overcome these limitations, a technique known as 
immunomarking - enzyme-linked immunosorbent assay (Elisa) - has been developed for marking insects. Its benefits include being of low cost, simple, nontoxic, rapid, sensitive, applicable on a large scale, and capable of marking small insects (Jasrotia \& Ben-Yakir, 2006; Williams et al., 2013). Therefore, this method may be used over large areas, to study the dispersion of insects, such as thrips.

Thrips (Thysanoptera: Thripidae) are a pest of onion (Allium cepa L.), tomato (Solanum lycopersicum L.), and potato (Solanum tuberosum L.) (Norris \& Kogan, 2005; Gonçalves \& Vieira Neto, 2011). Onion leaves fed on by thrips turn yellow, become twisted and dry, reducing bulb size (Cranshaw et al., 2005). Thrips cause severe infestations in Brazil, with densities of 13.26 nymphs of Thrips tabaci per plant, causing reduced yields (Gonçalves \& Vieira Neto, 2011). In tomato, potato, and onion crops, thrips cause problems related to sap sucking and virus transmission (Birithia et al., 2014; Dakshina et al., 2014).

One of the factors that accelerates the infestations and makes thrips difficult to control is their dispersion and spatial distribution potential (Helyer \& Brobyn, 1992). Understanding their spatial distribution may be one of the ways to improve chemical and biological controls, directing them toward areas of higher density and detecting the source of initial infestation (Carrillo et al., 2014). Moreover, these studies are important for defining the distances between crops, since polyphagous insects may migrate easily (Carrière et al., 2012). Carrillo et al. (2014) used semivariogram analysis, along with other spatial analyses, to examine the spatial dependence of thrips eggs on husk tomato (Physalis ixocarpa Brot.), a staple food crop in Mexico. These authors found that thrips have a clumped distribution in neighboring crops.

The objective of this work was to evaluate the spatial distribution of thrips in different crops, and the correlation between meteorological parameters and the flight movements of this pest, using immunomarking.

\section{Materials and Methods}

The experiment was conducted in 2011 and 2012 in the municipality of Rio Paranaíba, in the state of Minas Gerais, Brazil. The experimental areas were located in the region of Alto Paranaíba (Table 1), at 1,300 m of altitude. The local climate is dry, cold, and windy, with an average annual precipitation of $1,130-1,835 \mathrm{~mm}$. The experiments were conducted in autumn, from May $15^{\text {th }}$ to July $30^{\text {th }}, 2011$, and repeated in 2012. During the experiment, the temperature varied from 23 to $28^{\circ} \mathrm{C}$, the wind speed from 1.2 to $10.5 \mathrm{~m} \mathrm{~s}^{-1}$, and precipitation from 10 to $120 \mathrm{~mm}$ per month.

Trials were carried out on: two fields of tomato, Debora cultivar; one field of potato, Agata cultivar; one of onion, Andromeda cultivar (totaling $15 \mathrm{ha}$ ); and one of weeds (20 ha) (Table 1). To determine the main weedy plant species, 500 of them were sampled and the most frequent were: Raphanus raphanistrum (Brassicaceae); Ipomoea grandifolia (Convolvulaceae); Bidens pilosa, Conyza bonariensis, Ageratum conyzoides, and Emilia sonchifolia (Asteraceae); Euphorbia heterophylla (Euphorbiaceae); Sida spinosa (Malvaceae); and Nicandra physalodes (Solanaceae). Five hundred 245x100-mm blue sticky traps "Bio trap" (Biocontrole: Métodos de Controle de Pragas Ltda., Indaiatuba, SP, Brazil) (Muvea et al., 2014) were fixed to thin pieces of wood with $500 \times 20 \mathrm{~mm}$ of diameter each. Traps were placed throughout the trial area at $400 \mathrm{~mm}$ above the soil and at a $30-\mathrm{m}$ interval to ensure field coverage. The number of traps varied between areas, with 96-97 traps in the tomato and potato crops, 81 in the onion crop, and 130 in the area with weeds. The blue sticky traps were replaced every 15 days. The geographical position of each trap was recorded. To determine the point of origin (crop or weed area) of this insect, the marked plot with protein was georeferenced.

Three commercially available protein-specific Elisas were used with antibodies for soy protein S2519 (Sigma-Aldrich, São Paulo, SP, Brazil), chicken egg albumin C6534 (Sigma-Aldrich, São Paulo, SP, Brazil), and bovine casein PAB20025S (Biodesign International, Saco, ME, USA), a protein found in cow milk. The secondary antibodies used for the soy and chicken egg albumin assays were donkey anti-rabbit IgG $(\mathrm{H}+\mathrm{L})$ with a peroxidase conjugate A7340 (Sigma-Aldrich, São Paulo, SP, Brazil), and for the casein assay, a donkey anti-sheep IgG (whole molecule) peroxidase conjugate A3415 (Sigma-Aldrich, São Paulo, SP, Brazil).

The crop areas (tomato at 100 days of age and potato at 20 days) and the weedy plants (alternative hosts) were sprayed with casein, albumin, and soy 
protein, respectively, every 20 days, because they lasted more than 21 days in the field (Jones et al., 2006). The other areas (tomato at 10 days and onion at 50 days) were not sprayed (Table 1). The criteria for selecting treatment areas (sprayed) were: a function of age, and the distance between crops and alternative host plants. Twenty four hours before the proteins were sprayed, sampling (pre-evaluation) was performed with the blue traps, to detect the presence of thrips in the area. Protein concentrations were as follows: $10 \%$ albumin, $20 \%$ casein, and $20 \%$ soy protein. The proteins were diluted in distilled water and $0.3 \mathrm{~g} \mathrm{~L}^{-1}$ tetrasodium ethylenediaminetetraacetic acid-EDTA (Sigma-Aldrich, São Paulo, SP, Brazil). The spraying was done with a $20-\mathrm{L} \mathrm{CO}_{2}$ backpack sprayer, with 25 psi pressure, 26.5 GPA, and a spray volume of $500 \mathrm{~L} \mathrm{ha}^{-1}$. Twelve hours after spraying, the thrips captured in the traps were collected and stored individually in tubes containing $1 \mathrm{~mL}$ phosphate buffer saline solution at pH 8.0 T-664 (Sigma-Aldrich, São Paulo, SP, Brazil), for indirect Elisa analysis. The tubes containing the insects were identified according to location, previously georeferenced trap, and date of collection, in order to conduct spatial analysis. Wind speed data were obtained on assessment days at a meteorological station at the center of the study areas.

Indirect Elisa was performed on the protein solutions collected from treated adult thrips to determine the presence and intensity of protein markers. A total of 1-mL aliquots of marker protein solutions (milk, egg, or soy) in extraction buffer were transferred from each 1.5-mL centrifuge tube into individual wells of $96-$ well microplates SPL (Didática SP: Artigos e Equipamentos para Laboratório, Guarulhos, SP, Brazil). Likewise,

Table 1. Crop fields of tomato (Solanum lycopersicum), potato (Solanum tuberosum), and onion (Allium cepa) used to study the spatial distribution and flight movements of immunomarked thrips, as well as the proteins (antigens) used to spray the areas.

\begin{tabular}{lcccc}
\hline Fields & Location & $\begin{array}{c}\text { Age } \\
\text { (days) }\end{array}$ & $\begin{array}{c}\text { Phenological } \\
\text { phase }^{(1)}\end{array}$ & Protein \\
\hline Tomato & $19^{\circ} 11^{\prime} \mathrm{S}, 46^{\circ} 08^{\prime} \mathrm{W}$ & 100 & 2 & Bovine casein \\
Potato & $19^{\circ} 11^{\prime} \mathrm{S}, 46^{\circ} 07^{\prime} \mathrm{W}$ & 20 & 1 & Chicken egg albumin \\
Onion & $19^{\circ} 11^{\prime} \mathrm{S}, 46^{\circ} 07^{\prime} \mathrm{W}$ & 50 & 1 & Untreated \\
Tomato & $19^{\circ} 12^{\prime} \mathrm{S}, 46^{\circ} 08^{\prime} \mathrm{W}$ & 10 & 1 & Untreated \\
Weeds & $19^{\circ} 11^{\prime} \mathrm{S}, 46^{\circ} 08^{\prime} \mathrm{W}$ & 60 & 1 and 2 & Soy protein \\
\hline
\end{tabular}

(1) 1 , vegetative; and 2 , reproductive. $60-\mu \mathrm{L}$ aliquots of extraction buffer from the control treatments, as well as extraction buffer alone (blank), were transferred into individual microplate wells, which served as negative controls and blanks. Each Elisa plate had 8-16 negative control thrips (Jones et al., 2006). The individuals were designated as marked or unmarked based on the amount of foreign protein detected by Elisa.

The percentage of protein-marked adult thrips captured per trap was calculated. Since each trap was georeferenced, it was possible to determine the destinations of the thrips and construct spatial distribution maps considering total marked and unmarked insects.

In addition, the parameters nugget effect $\left(\mathrm{C}_{0}\right)$, sill effect $\left(\mathrm{C}_{0}+\mathrm{C}\right)$, and range of spatial dependence $\left(\mathrm{A}_{0}\right)$ were used to calculate the ratio between the nugget and sill effect in order to identify the spatial dependence degree (SDD). To analyze the SDD of the studied attributes, the classification proposed by Cambardella et al. (1994) was used, in which: semivariograms with strong SDD have a ratio of $\mathrm{C}_{0} /\left(\mathrm{C}_{0}+\mathrm{C}\right)$ that is less than or equal to 0.25 ; semivariograms with a moderate spatial dependence have a ratio greater than 0.25 and up to 0.75 , and include curve models, such as the exponential, Gaussian, or spherical ones; and those with a weak spatial dependence have a ratio greater than 0.75 . The semivariogram functions quantify the assumption that things that are closer to each other tend to be more similar than things farther away. The semivariogram can be estimated by

$$
\mathrm{Y}(\mathrm{h})=\frac{1}{2 \mathrm{n}(\mathrm{h})} \sum_{\mathrm{i}=1}^{\mathrm{n}}[\mathrm{x}(\mathrm{i}+\mathrm{h})-\mathrm{x}(\mathrm{i})]^{2},
$$

in which: $Y(h)$ is the semivariogram function at $h$ distance; $n$ is the number of pairs of points separated at $\mathrm{h}$ distance; $\mathrm{x}$ is the number of thrips per trap; $\mathrm{i}$ is the point; and $\mathrm{h}$ is the distance in $\mathrm{km}$.

After determining the spatial dependence between samples, the kriging statistical interpolation method was used to construct the population density map and to estimate sampled values (Rhodes et al., 2011). Kriging is an interpolation technique that predicts unknown variables from data observed at known locations. It uses semivariograms to show spatial variability and reduces the error of predicted variables. Pearson's correlation analysis $(\mathrm{p}<0.05)$ was carried out to relate 
wind speed $\left(\mathrm{m} \mathrm{s}^{-1}\right)$, temperature, and precipitation with population infestations every 15 days.

\section{Results and Discussion}

The thrips species found were: Thrips tabaci (onion and tomato), Frankliniella occidentalis (tomato and potato), F. schultzei (tomato and potato), and T. palmi (onion and potato). The average captures of adult thrips were: $458 \pm 3.25$ in tomato at 100 days of age; $321 \pm 5.31$ in tomato at 10 days of age; $513 \pm 10.22$ in onion; $304 \pm 15.43$ in potato; and $35 \pm 1.02$ in weeds. Of the 1,631 captured insects, $1,341(78.39 \%)$ were marked with the three proteins used during the study period. The percentages of thrips marked with the albumin, casein, and soy milk proteins were $63.50,84.81$, and $86.85 \%$, respectively.

The high number of marked thrips and the detection of all the proteins in field conditions show that this method may be used to mark thrips and study their dispersion (Jasrotia \& Ben-Yakir, 2006). Smaller insects have been marked by Hagler \& Jackson (2002), who identified thousands of minute parasitoids with small quantities of inexpensive immune label.

A significant positive correlation was observed between the number of thrips marked with casein and wind speed $(r=0.74 ; p<0.001)$, but no relationship was found between wind speed and thrips marked with albumin $(\mathrm{r}=0.11 ; \mathrm{p}>0.01)$ or soy protein $(\mathrm{r}=0.32 ; \mathrm{p}>0.01)$. There was no significant correlation between the meteorological parameters (temperature and precipitation) and the number of thrips marked with casein $\left(\mathrm{r}_{\text {temperature }}=0.08, \mathrm{p}>0.01 ; \mathrm{r}_{\text {precipitation }}=0.02\right.$, $\mathrm{p}>0.01)$, albumin $\left(\mathrm{r}_{\text {temperature }}=0.10, \mathrm{p}>0.01 ; \mathrm{r}_{\text {precipitation }}\right.$ $=0.15, \mathrm{p}>0.01)$, and soy protein $\left(\mathrm{r}_{\text {temperature }}=0.21\right.$, $\left.\mathrm{p}>0.01 ; \mathrm{r}_{\text {precipitation }}=0.17, \mathrm{p}>0.01\right)$. These results were expected, since there was little variation in temperature (18\%) and precipitation (13\%) during the experimental period (Table 2).

The significant positive correlation between thrips densities and wind speed is predictable and reasonably justified, since insects can be passively transported by the wind (Arévalo \& Liburd, 2007). Therefore, local common activities should be performed during light winds, since stronger winds and higher altitudes can favor insect migration.

A spatial dependence of thrips densities was observed in the experimental areas each day after spraying. This means that the spatial distribution of the adult thrips is dependent on the conditions of the habitat, with some areas having higher densities than others (Ribeiro Jr et al., 2009). In general, the models showed different values for range $\left(\mathrm{A}_{0}\right)$ and sill effect $\left(\mathrm{C}+\mathrm{C}_{0}\right)$. The difference between these two parameters explained the high spatial dependence values. The $A_{o}$ range of the selected models varied between 0.20 and $3.5 \mathrm{~km}$. The mean SDD was 0.33 , showing a moderate degree of dependence on the spatial continuity structure (Figure 1 and Table 3).

The highest and lowest ranges $\left(\mathrm{A}_{\mathrm{o}}\right)$ of the semivariogram showed that crop separation was an important factor in the habitat recolonization process and may explain the spatial distribution of thrips (Ribeiro Jr et al., 2009). Nault et al. (2003) studied the

Table 2. Meteorological parameters of commercial crop fields of tomato (Solanum lycopersicum), potato (Solanum tuberosum), and onion (Allium cepa) used to study correlation with the flight movements of immunomarked thrips.

\begin{tabular}{|c|c|c|c|c|c|c|c|c|c|c|}
\hline \multirow[t]{2}{*}{ Climatic parameter } & \multicolumn{2}{|c|}{ Tomato field 1} & \multicolumn{2}{|c|}{ Tomato field 2} & \multicolumn{2}{|c|}{ Potato } & \multicolumn{2}{|c|}{ Onion } & \multicolumn{2}{|c|}{ Weeds } \\
\hline & 2011 & 2012 & 2011 & 2012 & 2011 & 2012 & 2011 & 2012 & 2011 & 2012 \\
\hline & \multicolumn{10}{|c|}{ May } \\
\hline Precipitation (mm) & 120.21 & 12.14 & 38.33 & 19.54 & 35.06 & 10.32 & 37.85 & 19.10 & 38.64 & 15.06 \\
\hline Temperature $\left({ }^{\circ} \mathrm{C}\right)$ & 27.04 & 25.47 & 28.00 & 25.12 & 24.11 & 26.11 & 25.14 & 26.32 & 26.74 & 27.10 \\
\hline \multirow[t]{2}{*}{ Wind speed $\left(\mathrm{m} \mathrm{s}^{-1}\right)$} & 1.02 & 1.55 & 5.02 & 1.22 & 9.11 & 8.15 & 10.05 & 9.28 & 10.48 & 10.01 \\
\hline & \multicolumn{10}{|c|}{ June } \\
\hline Precipitation (mm) & 12.11 & 10.14 & 10.33 & 10.54 & 10.44 & 10.11 & 10.98 & 10.33 & 10.91 & 10.65 \\
\hline Temperature $\left({ }^{\circ} \mathrm{C}\right)$ & 24.05 & 26.12 & 24.01 & 25.02 & 23.01 & 24.00 & 23.02 & 23.11 & 23.00 & 23.10 \\
\hline \multirow[t]{2}{*}{ Wind speed $\left(\mathrm{m} \mathrm{s}^{-1}\right)$} & 10.50 & 1.51 & 5.02 & 1.65 & 9.63 & 8.74 & 8.05 & 9.18 & 10.33 & 10.00 \\
\hline & \multicolumn{10}{|c|}{ July } \\
\hline Precipitation (mm) & 10.23 & 10.13 & 12.61 & 10.51 & 15.02 & 10.02 & 17.22 & 0.33 & 11.11 & 11.33 \\
\hline Temperature $\left({ }^{\circ} \mathrm{C}\right)$ & 24.00 & 25.15 & 24.02 & 25.22 & 24.10 & 23.01 & 23.14 & 26.38 & 23.04 & 23.11 \\
\hline Wind speed $\left(\mathrm{m} \mathrm{s}^{-1}\right)$ & 3.02 & 4.65 & 1.22 & 0.65 & 0.61 & 0.11 & 1.05 & 1.01 & 1.03 & 1.08 \\
\hline
\end{tabular}


dispersion and seasonality of $F$. fusca (Hinds) tomato crops spaced $8 \mathrm{~km}$ apart and reported the dispersion of the species in these areas.
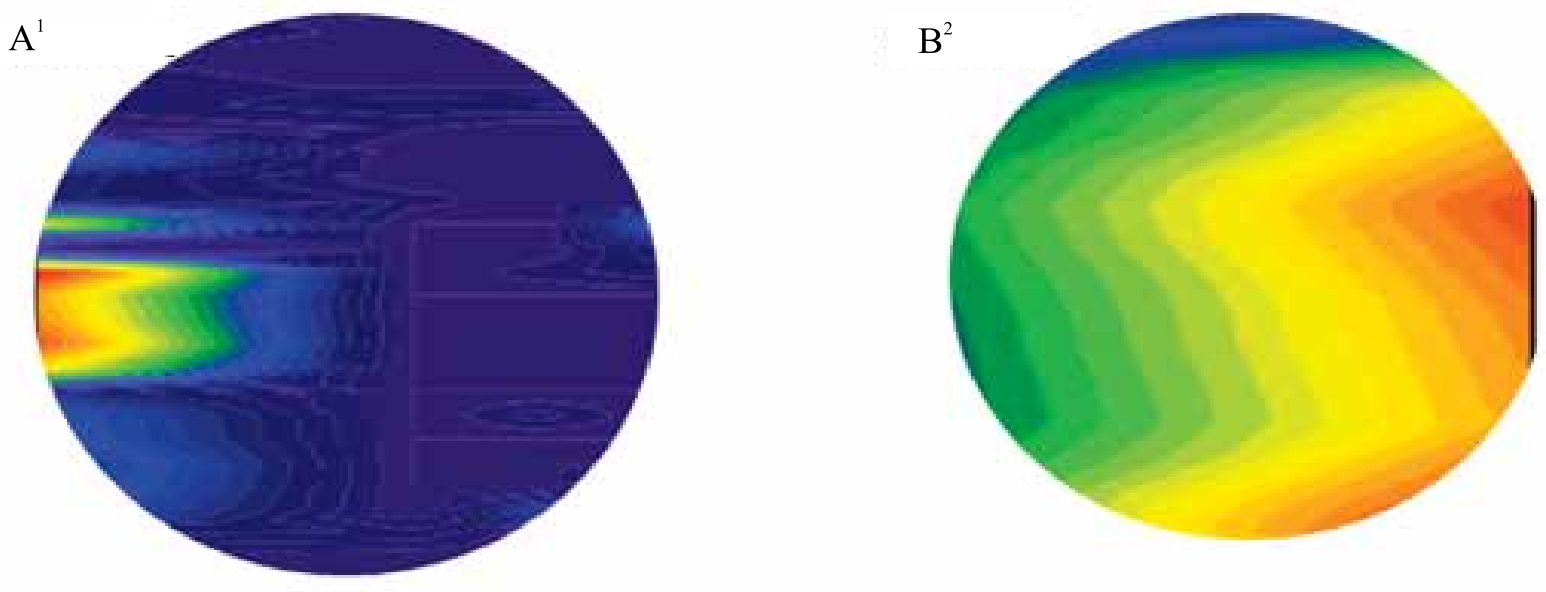

High densities of thrips marked with casein were observed migrating in the tomato area (100 days), from the edges to the center of the crop. These adult thrips

$\mathrm{C}^{3}$
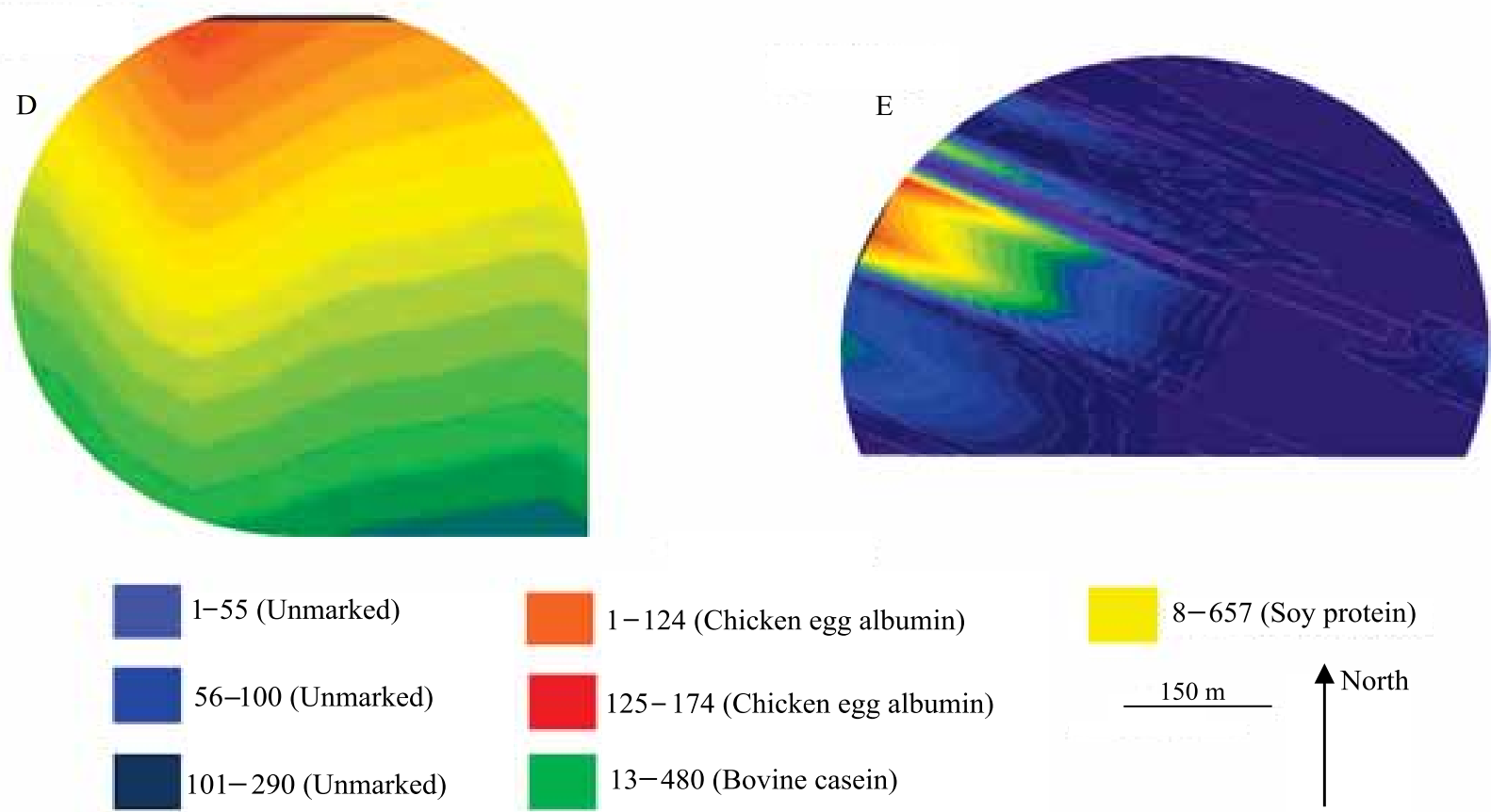

1-55 (Unmarked)

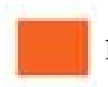

1-124 (Chicken egg albumin)

56-100 (Unmarked)

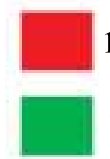

125-174 (Chicken egg albumin)

13-480 (Bovine casein)

Figure 1. Maps of thrips spatial distribution marked with the casein ${ }^{(1)}$, albumin ${ }^{(2)}$, and soy milk ${ }^{(3)}$ proteins in areas with: A, tomato (Solanum lycopersicum) at 100 days; B, potato (Solanum tuberosum) at 20 days; C, weeds; D, tomato (Solanum lycopersicum) at 10 days, and E, onion (Allium cepa) at 50 days. Colors represent accumulation densities of thrips per trap, and whether or not the insects were marked with a specific protein. 
also migrated to other study areas, coinciding with western-eastern winds $(65 \%)$ and northern-southern winds $(29 \%)$. Thrips with the albumin marker were found in potato crops after 20 days, as well as at the edges of the weeds and at the edges of younger onion (50 days) and tomato (10 days) crops. The thrips migrate in the direction from the older (tomato) to the younger crops (potato) (Figure 1), which was confirmed by the fact that insects marked with protein were found in the newest crops.

If insect movement is governed in part by wind, the distribution and density of these organisms should be affected by this factor. However, winds are not necessarily the immediate causes of migration, since environmental conditions (weather) and food quality are also related to this phenomenon. Migration can be better interpreted as a tool used by individuals to maximize their reproductive success. Variations in temperature, precipitation, resource abundance, population density, and attacks from natural enemies are the most probable stimuli directly associated with migration (Hance et al., 2007).

Resource quality is another important factor. The quality of nourishment for phytophagous insects is determined by phytochemicals and leaf toughness. As such, higher leaf toughness can reduce consumption, prolong developmental time, and diminish the survival of phytophagous insects (Johnson \& Gregory, 2006). Although these physiological disturbances may be important, it was not possible to investigate them in the present study.

Thrips, like any polyphagous insect, explore new habitats to find suitable host plants that are

Table 3. Nugget effect $\left(\mathrm{C}_{\mathrm{o}}\right)$, sill effect $\left(\mathrm{C}+\mathrm{C}_{\mathrm{o}}\right)$, spatial dependence degree (SDD), and range $\left(\mathrm{A}_{0}\right)$ of semivariogram data, obtained by the spherical, exponential, and Gaussian models, of thrips captured in blue sticky traps in commercial crops of tomato (Solanum lycopersicum), potato (Solanum tuberosum), and onion (Allium cepa), and in an area with weeds at 2, 7, 14, 21, and 28 days after spraying (DAS).

\begin{tabular}{lccccc}
\hline DAS & Model & $\mathrm{C}_{\mathrm{o}}$ & $\mathrm{C}+\mathrm{C}_{\mathrm{o}}$ & $\mathrm{SDD}^{(1)}$ & $\mathrm{A}_{0}(\mathrm{~km})$ \\
\hline 2 & Spherical & 1.354 & 2.841 & 0.48 & 0.41 \\
7 & Gaussian & 2.574 & 6.287 & 0.41 & 0.20 \\
14 & Exponential & 1.025 & 5.041 & 0.20 & 0.50 \\
21 & Gaussian & 3.054 & 9.117 & 0.33 & 3.15 \\
28 & Gaussian & 2.087 & 10.051 & 0.21 & 3.50 \\
${ }^{(1)} \mathrm{C}_{0} /\left(\mathrm{C}_{0}+\mathrm{C}\right)$. & & & & &
\end{tabular}

Pesq. agropec. bras., Brasília, v.50, n.5, p.399-406, maio 2015 DOI: 10.1590/S0100-204X2015000500007 sustainable for their reproduction (Kennedy \& Storer, 2000). Furthermore, polyphagous insect herbivores usually exhibit clear preferences for particular plant species or plant-growth stages (Liu et al., 2010), scrapping leaves and feeding on younger tissues. In the present study, the thrips migrated from the 100-day-old tomato crop to the 20 -day-old tomato crop. This migration may be caused by the tomato itself, which, at 100 days of age, had a high lignin content that impaired insect feeding and oviposition (Peeters, 2002; Compson et al., 2013; Dowd et al., 2013). Even though older tomato plants have shoots, which are considered the preferred niche for thrips, younger plants have higher quantities of young tissues (shoots) that favor insect feeding and oviposition. The migration of the thrips to the areas with weedy plants may be due to the presence of plants in the flowering stage, since these are attractive to these insects (Norris \& Kogan, 2005).

Thrips dispersion is dependent on the species of thrips encountered (Funderburk \& Stavisky, 2004), and the potential of thrips to explore different habitats was shown in the present study. Producers must pay attention to crop spacing in the habitat, controlling weedy plants and considering that thrips leave the older crops for the younger ones. Wind may be one of the meteorological parameters favorable to migration. In this way, vegetable producers should scale their production to reduce the period when the plants are in the field. Studies of biotic and abiotic factors that interfere in thrips dispersal are encouraged to be done in field conditions.

\section{Conclusions}

1. The immunomarcation method, using different proteins, is efficient to mark large quantities of thrips.

2. The spatial distribution of thrips is dependent on the habitat.

3. Thrips disperse from older (tomato) to younger crops (potato).

\section{Acknowledgments}

To Fundação Arthur Bernardes (Funarbe) and to Programa de Apoio à Pesquisa para Jovens Docentes Pesquisadores (Funarpeq), for financial support. 


\section{References}

ARÉVALO, H.A.; LIBURD, O.E. Horizontal and vertical distribution of flower thrips in southern highbush and rabbiteye blueberry fields, with notes on a new sampling method for thrips inside the flowers. Journal of Economic Entomology, v.100, p.1622-1632, 2007. DOI: 10.1093/jee/100.5.1622.

BIRITHIA, R.K.; SUBRAMANIAN, S.; MUTHOMI, J.W.; NARLA, R.D. Resistance to Iris yellow spot virus and onion thrips among onion varieties grown in Kenya. International Journal of Tropical Insect Science, v.34, p.73-79, 2014. DOI: 10.1017/ s1742758414000289.

CAMBARDELLA, C.A.; MOORMAN, T.B.; PARKIN, T.B.; KARLEN, D.L.; NOVAK, J.M.; TURCO, R.F.; KONOPKA, A.E. Field-scale variability of soil properties in Central Iowa soils. Soil Science Society of America Journal, v.58, p.1501-1511, 1994. DOI: 10.2136/sssaj1994.03615995005800050033x.

CARRIÈRE， Y.; GOODELL， P.B.; ELLERS-KIRK， C.; LAROCQUE, G.; DUTILLEUL, P.; NARANJO, S.E.; ELLSWORTH P.C. Effects of local and landscape factors on population dynamics of a cotton pest. Plos One, v.7, e39862, 2012. DOI: 10.1371/journal.pone.0039862.

CARRILLO, R.A.J.; DÁVILA, J.F.R.; PALE, J.R.S.; SICLÁN, M.L.S.; CERDA, A.L. Modelización especial de huevos de Thrips (Thysanoptera: Frankliniella occidentalis) en tomate de cáscara por medio de técnicas geoestadísticas. Revista de la Facultad de Ciencias Agrarias UNCuyo, v.46, p.29-44, 2014.

COMPSON, Z.G.; ADAMS, K.J.; EDWARDS, J.A.; MAESTAS, J.M.; WHITHAM, T.G.; MARKS, J.C. Leaf litter quality affects aquatic insect emergence: contrasting patterns from two foundation trees. Oecologia, v.173, p.507-519, 2013. DOI: 10.1007/ s00442-013-2643-6.

CRANSHAW, W.; GRAFIUS, E.; LIU, T.X.; NAULT, B.; RILEY, D. Onions. In: FOSTER, R.; FLOOD, B. (Ed.). Vegetable insect management. Willoughby: Meister, 2005.

DAKSHINA, R.S.; KUMAR, V.; KAKKAR, G. Common blossom thrips, Frankliniella schultzei (Thysanoptera: Thripidae) management and Groundnut ring spot virus prevention on tomato and pepper in Southern Florida. Florida Entomologist, v.97, p.374-383, 2014. DOI: 10.1653/024.097.0206.

DOWD, P.F.; SARATH, G.; MITCHELL, R.B.; SAATHOFF, A.J.; VOGEL, K.P. Insect resistance of a full sib family of tetraploid switchgrass Panicum virgatum L. with varying lignin levels. Genetic Resources and Crop Evolution, v.60, p.975-984, 2013. DOI: $10.1007 / \mathrm{s} 10722-012-9893-8$.

FUNDERBURK, J.; STAVISKY, J. Biology and economic importance of flower thrips. Gainesville: Institute of Food and Agricultural Sciences, University of Florida, 2004.

GONÇALVES, P.A. de S.; VIEIRA NETO, J. Influência da incidência de tripes, Thrips tabaci Lind. (Thysanoptera: Thripidae) na produtividade de cebola em sistemas convencional e orgânico. Revista Brasileira de Agroecologia, v.6, p.152-158, 2011.

HAGLER, J.R.; JACKSON, C.G. Methods for marking insects: current techniques and future prospects. Annual Review of
Entomology, v.46, p.511-543, 2001. DOI: 10.1146/annurev. ento.46.1.511.

HAGLER， J.R.; JACKSON， C.G.; HENNEBERRY， T.J.; GOULD, J.R. Parasitoid mark-release-recapture techniques: II. Development and application of a protein marking technique for Eretmocerus spp., parasitoids of Bemisia argentifolii. Biocontrol Science and Technology, v.12, p.661-675, 2002. DOI: $10.1080 / 0958315021000039851$.

HANCE, T.; VAN BAAREN, J.; VERNON, P.; BOIVIN, G. Impact of extreme temperatures on parasitoids in a climate change perspective. Annual Review of Entomology, v.52, p.107-126, 2007. DOI: 10.1146/annurev.ento.52.110405.091333.

HELYER, N.L.; BROBYN, P.J. Chemical control of western flower thrips (Frankliniella occidentalis Pergande). Annals of Applied Biology, v.121, p.219-231, 1992. DOI: 10.1111/j.1744-7348.1992. tb03434.x.

JASROTIA, P.; BEN-YAKIR, D. An immuno-marking technique for thrips. Entomologia Experimentalis et Applicata, v.120, p.155-160, 2006. DOI: 10.1111/j.1570-7458.2006.00442.x.

JOHNSON, S.N.; GREGORY, P.J. Chemically-mediated host-plant location and selection by root-feeding insects. Physiological Entomology, v.31, p.1-13, 2006. DOI: 10.1111/j.1365-3032.2005 .00487.x.

JONES, V.P.; HAGLER, J.R.; BRUNNER, J.F.; BAKER, C.C.; WILBURN, T.D. An inexpensive immunomarking technique for studying movement patterns of naturally occurring insect populations. Environmental Entomology, v.35, p.827-836, 2006. DOI: $10.1603 / 0046-225 x-35.4 .827$.

KENNEDY, G.G.; STORER, N.P. Life systems of polyphagous arthropod pests in temporally unstable cropping systems. Annual Review of Entomology, v.45, p.467-493, 2000. DOI: 10.1146/ annurev.ento.45.1.467.

LIU, Z.; SCHEIRS, J.; HECKEL, D.G. Host plant flowering increases both adult oviposition preference and larval performance of a generalist herbivore. Environmental Entomology, v.39, p.552-560, 2010. DOI: 10.1603/EN09129.

MUVEA, A.M.; WAIGANJO, M.M.; KUTIMA, H.L.; OSIEMO, Z.; NYASANI, J.O.; SUBRAMANIAN, S. Attraction of pest thrips (Thysanoptera: Thripidae) infesting French beans to coloured sticky traps with Lurem-TR and its utility for monitoring thrips populations. International Journal of Tropical Insect Science, v.34, p.197-206, 2014. DOI: 10.1017/S174275841400040X.

NAULT, B.A.; SPEESE, J.; JOLLY, D.; GROVES, R.L. Seasonal patterns of adult thrips dispersal and implications for management in Eastern Virginia tomato fields. Crop Protection, v.22, p.505-512, 2003. DOI: 10.1016/S0261-2194(02)00203-X.

NORRIS, R.F.; KOGAN, M. Ecology of interactions between weeds and arthropods. Annual Review of Entomology, v.50, p.479-503, 2005. DOI: 10.1146/annurev.ento.49.061802.123218.

PEDIGO, L.P.; RICE, M.E. Entomology and pest management. $6^{\text {th }}$ ed. Upper Saddle River: Pearson Prentice Hall, 2009. 816p.

PEETERS, P.J. Correlations between leaf constituent levels and the densities of herbivorous insect guilds in an Australian forest. Austral Ecology, v.27, p.658-671, 2002. DOI: 10.1046/j.1442-99 93.2002.01227.x. 
RHODES, E.M.; LIBURD, O.E.; GRUNWALD, S. Examining the spatial distribution of flower thrips in southern highbush blueberries by utilizing geostatistical methods. Environmental Entomology, v.40, p.893-903, 2011. DOI: 10.1603/EN10312.

RIBEIRO JR, P.J.; VIOLA, D.N.; DEMÉTRIO, C.G.B.; MANLY, B.F.; FERNANDES, O.A. Spatial pattern detection modeling of thrips (Thrips tabaci) on onion fields. Scientia Agricola, v.66, p.90-99, 2009. DOI: 10.1590/S0103-90162009000100013.

WILLIAMS, L.; HAGLER, J.R.; TONKEL, K.C. Does dimethyl sulfoxide increase protein immunomarking efficiency for dispersal and predation studies? Entomologia Experimentalis et Applicata, v.148, p.275-286, 2013. DOI: 10.1111/eea.12100.

Received on December 01, 2014 and accepted on April 15, 2015 